\title{
APOE Isoforms Control Pathogenic Subretinal Inflammation in Age-Related Macular Degeneration
}

\author{
Olivier Levy, ${ }^{1,2,3}$ - Sophie Lavalette, ${ }^{1,2,3}$ Shulong J. Hu, ${ }^{1,2,3}$ Michael Housset, ${ }^{1,2,3}$ William Raoul, ${ }^{1,2,3}$ Chiara Eandi, ${ }^{5}$ \\ () José-Alain Sahel, ${ }^{1,2,3,4}$ Patrick M. Sullivan, ${ }^{6}$ (Xavier Guillonneau, ${ }^{1,2,3}$ and ${ }^{\circledR}$ Florian Sennlaub ${ }^{1,2,3}$ \\ ${ }^{1}$ Institut National de la Santé et de la Recherche Médicale, U 968, Paris, F-75012, France, ${ }^{2}$ Sorbonne Universités, Université Pierre et Marie Curie Paris 06, \\ Unité Mixte de Recherche S 968, Institut de la Vision, Paris, F-75012, France, ${ }^{3} \mathrm{CNRS}$, Unité Mixte de Recherche 7210, Paris, F-75012, France, ${ }^{4}$ Centre \\ Hospitalier National d'Ophtalmologie des Quinze-Vingts, Institut National de la Santé et de la Recherche Médicale-DHOS CIC 503, Paris, F-75012, France, \\ ${ }^{5}$ Department of Surgical Sciences, Eye Clinic, University of Torino, Torino, Italy, and ${ }^{\circ}$ Department of Medicine, Centers for Aging and Geriatric Research \\ Education and Clinical Center, Durham Veteran Affairs Medical Center, Duke University, Durham, North Carolina 27710
}

Contrary to Alzheimer's disease (AD), the APOE2 allele increases and the APOE4 allele reduces the risk to develop age-related macular degeneration (AMD) compared with the most common $A P O E 3$ allele. The underlying mechanism for this association with AMD and the reason for the puzzling difference with $\mathrm{AD}$ are unknown. We previously demonstrated that pathogenic subretinal mononuclear phagocytes (MPs) accumulate in Cx3crl-deficient mice due to the overexpression of APOE, interleukin-6, and CC chemokine ligand 2 (CCL2). We here show using targeted replacement mice expressing the human APOE isoforms (TRE2, TRE3, and TRE4) that MPs of TRE2 mice express increased levels of APOE, interleukin-6, and CCL2 and develop subretinal MP accumulation, photoreceptor degeneration, and exaggerated choroidal neovascularization similar to AMD. Pharmacological inhibition of the cytokine induction inhibited the pathogenic subretinal inflammation. In the context of APOE-dependent subretinal inflammation in $C x 3 c r 1^{G F P / G F P}$ mice, the APOE4 allele led to diminished APOE and CCL2 levels and protected $C \times 3 c r 1^{\text {GFP/GFP }}$ mice against harmful subretinal MP accumulation observed in $C \times 3 c r 1^{G F P / G F P}$ TRE3 mice. Our study shows that pathogenic subretinal inflammation is APOE isoform-dependent and provides the rationale for the previously unexplained implication of the APOE2 isoform as a risk factor and the APOE4 isoform as a protective factor in AMD pathogenesis.

Key words: apolipoprotein E; mononuclear phagocyte; neurodegeneration; neuroinflammation

Significance Statement

The understanding of how genetic predisposing factors, which play a major role in age-related macular degeneration (AMD), participate in its pathogenesis is an important clue to decipher the pathomechanism and develop efficient therapies. In this study, we used transgenic, targeted replacement mice that carry the three human APOE isoform-defining sequences at the mouse APOE chromosomal location and express the human APOE isoforms. Our study is the first to show how APOE2 provokes and APOE4 inhibits the cardinal AMD features, inflammation, degeneration, and exaggerated neovascularization. Our findings reflect the clinical association of the genetic predisposition that was recently confirmed in a major pooled analysis. They emphasize the role of APOE in inflammation and inflammation in AMD.

\section{Introduction}

In humans, the $A P O E$ gene has three common genetic variants (APOE2, APOE3, and APOE4), due to two polymorphisms rs7412 and rs429358 that are imbedded in a well-defined CpG island, and lead to two cysteine-arginine interchanges at residues
112 and 158 (Yu et al., 2013). The APOE2 allele is associated with higher APOE concentrations in plasma, CSF, and brain tissue (Riddell et al., 2008; Bales et al., 2009) due to impaired clearance caused by APOE2's decreased affinity for the low-density lipoprotein receptor (Mahley and Rall, 2000). Its transcription can

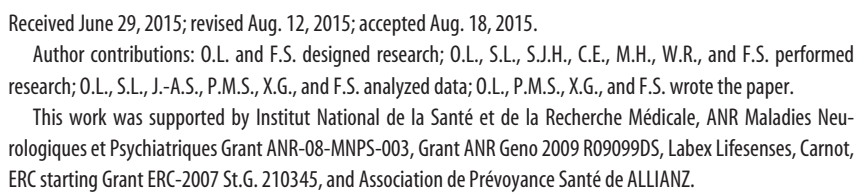

The authors declare no competing financial interests.

Correspondence should be addressed to Dr. Florian Sennlaub, Institut National de la Santé et de la Recherche Médicale, Unité Mixte de Recherche S 968, Institut de la Vision, Paris, F-75012, France. E-mail: florian.sennlaub@inserm.fr.

DOI:10.1523/JNEUROSCI.2468-15.2015

Copyright $\odot 2015$ the authors $\quad 0270-6474 / 15 / 3513568-09 \$ 15.00 / 0$ 
also be increased in certain cell types (astrocytes, neurons) due to the loss of $\mathrm{CpG}$ sites associated with $A P O E 3$ and APOE4 alleles (Yu et al., 2013). Compared with the APOE3 allele, the APOE4 allele is transcribed similarly in neurons and astrocytes (Yu et al., 2013), but its protein concentrations in plasma, CSF, and brain parenchyma are decreased (Riddell et al., 2008; Bales et al., 2009; Sullivan et al., 2011). The structural changes in the APOE4 protein also lead to diminished association with high-density lipoprotein (Dong and Weisgraber, 1996) and impaired reverse cholesterol transport (Heeren et al., 2004; Mahley et al., 2009).

APOE2 allele carriers are at increased risk for developing late age-related macular degeneration (AMD) [odds ratio $(\mathrm{OR})=$ 1.83 for homozygote APOE2 allele carriers] and are protected against Alzheimer's disease (AD), whereas the APOE4 allele protects against $\mathrm{AMD}(\mathrm{OR}=0.72$ per haplotype $)$ and is a risk factor for AD compared with the most common APOE3 allele (Mahley and Rall, 2000; McKay et al., 2011). This association was recently confirmed in a pooled study of $>20,000$ subjects (McKay et al., 2011). It is found for both clinical forms of late AMD: wet AMD, which is defined by choroidal neovascularization (CNV) and geographic atrophy, which is characterized by an extending lesion of both the retinal pigment epithelium (RPE) and photoreceptors. In $\mathrm{AD}$, the APOE4 allele is associated with greater $\beta$-amyloid burden, possibly due to reduced efficacy in clearance of $\beta$-amyloid via multiple pathways (Bales et al., 2009; Mahley et al., 2009). The mechanism underlying the associations of the APOE isoforms with AMD remains unexplained.

APOE is the main lipoprotein of the brain and the retina (Mahley and Rall, 2000; Anderson et al., 2001). It is strongly expressed in mononuclear phagocytes (MPs), such as macrophages and microglial cells (Peri and Nüsslein-Volhard, 2008; Levy et al., 2015), and plays a major role in macrophage lipid efflux and reverse cholesterol transport in conjunction with APOA-I (Mahley and Rall, 2000; Mahley et al., 2009). APOE and APOA-I can also induce interleukin-6 (IL-6) and CC chemokine ligand 2 (CCL2) in MPs in the absence of pathogen-derived ligands (Smoak et al., 2010; Levy et al., 2015).

We recently showed that subretinal MPs that accumulate in AMD strongly express APOE (Levy et al., 2015). The subretinal MPs of $C \times 3 \mathrm{crl}^{\text {GFP/GFP }}$ mice that develop subretinal inflammation and cardinal features of AMD (Combadière et al., 2007) express similar high levels of APOE (Levy et al., 2015), but also IL-6 (Levy et al., 2015) and CCL2 (Sennlaub et al., 2013). We showed that APOE-induced IL-6 release from MPs represses RPE immune suppression, prolongs subretinal MP survival, and promotes subretinal inflammation (Levy et al., 2015). Furthermore, we demonstrated that increased levels of CCL2 in $C x 3 c r 1^{\text {GFP/GFP }}$ mice recruit pathogenic inflammatory CCR $2{ }^{+}$monocytes to the subretinal space (Sennlaub et al., 2013). In consequence, subretinal pathogenic MPs accumulate in $C \times 3 c r 1^{G F P / G F P}$ mice due to increased MP recruitment and decreased MP elimination. ApoE deletion in $C \times 3 c r 1^{G F P / G F P}$ mice prevented age- and stress-induced subretinal MP accumulation and reduced associated CNV (Levy et al., 2015).

We here investigated the influence of the APOE alleles and isoforms on subretinal inflammation and associated photoreceptor degeneration and choroidal neovascularization, major hallmarks of AMD.

\section{Materials and Methods}

Animals. Targeted replacement mice that express human APOE isoforms (TRE2, TRE3, and TRE4) were engineered as previously described (Sullivan et al., 1997) and provided as a generous gift by Dr. Patrick Sullivan, backcrossed with C57BL/6 mice to eliminate the $\mathrm{Crb} 1{ }^{\mathrm{rd} 8}$ contamination in the three strains and crossed to $C \times 3 c r 1^{\text {GFP/GFP }}$ mice (Charles River). Mice were housed in the animal facility under specific pathogen-free condition, in a 12/12 h light/dark (100-500 lux) cycle with water and normal diet food available ad libitum. All experimental protocols and procedures were approved by the local animal care ethics committee "Comité d'éthique en expérimentation animale Charles Darwin" (Ce5/ 2010/013; Ce5/2011/033; Ce5/2010/044). We used male mice for choroidal neovascularization experiments, whereas experiments on aged and light challenged mice were performed on mice of either sex, as we did not observe differences between the sexes in these conditions.

Light challenge and laser injury model. Two-month-old mice of either sex were adapted to darkness for $6 \mathrm{~h}$, pupils dilated and exposed to constant green LED light (starting at 2 A.M., 4500 lux, JP Vezon equipements) for $4 \mathrm{~d}$ as previously described (Sennlaub et al., 2013). Laser coagulations were performed on male mice with a $532 \mathrm{~nm}$ ophthalmological laser mounted on an operating microscope (Vitra Laser, $532 \mathrm{~nm}$, $450 \mathrm{~mW}, 50 \mathrm{~ms}, 250 \mu \mathrm{m}$ ) as previously described (Levy et al., 2015). Intravitreal injections of $2 \mu \mathrm{l}$ of PBS, isotype control rat IgG1, and rat anti-mouse CD14 (BD Biosciences) were performed using glass capillaries (Eppendorf) and a microinjector. The $2 \mu \mathrm{l}$ solution of the antibodies was injected at $50 \mu \mathrm{g} / \mathrm{ml}$, corresponding to an intraocular concentration of $5 \mu \mathrm{g} / \mathrm{ml}$ assuming their dilution by $\sim 1 / 10$ th in the intraocular volume.

Immunohistochemistry, $C N V$, and $M P$ quantification and histology. RPE and retinal flatmounts were stained and quantified as previously described (Sennlaub et al., 2013) using polyclonal rabbit anti-IBA-1 (Wako) and rat anti-mouse CD102 (clone 3C4, BD Biosciences) appropriate secondary antibodies and counterstained with Hoechst if indicated. Preparations were observed with fluorescence microscope (DM5500, Leica). Histology of mice eyes and photoreceptor quantification were performed as previously described (Sennlaub et al., 2013).

Cell preparations and cell culture. In accordance with the Declaration of Helsinki, volunteers provided written and informed consent for the human monocyte expression studies, which were approved by the Centre national d'ophthalmologie des Quinze-Vingt hospital (Paris) ethics committees (no. 913572). Peripheral blood mononuclear cells were isolated from heparinized venous blood from healthy volunteer individuals by 1-step centrifugation on a Ficoll Paque layer (GE Healthcare) and sorted with EasySep Human Monocyte Enrichment Cocktail without CD16 Depletion Kit (Stem Cell Technology). Mouse peritoneal macrophages, bone marrow-derived monocytes, and photoreceptor outer segment (POS) isolation (all in serum-free X-Vivo 15 medium) were performed as previously described (Sennlaub et al., 2013). In specific experiments, cells were stimulated with the different recombinant human APOE isoforms ( $5 \mu \mathrm{g} / \mathrm{ml}$, Leinco Technologies), recombinant human APOE3 $90 \mathrm{~min}$ heat-denatured ( $5 \mu \mathrm{g} / \mathrm{ml}$, Leinco Technologies), APOE3 $(5 \mu \mathrm{g} / \mathrm{ml})$ with LPS inhibitor polymyxin B $(25 \mu \mathrm{g} / \mathrm{ml}$, Calbiochem), rat anti-IgG isotype control ( $25 \mu \mathrm{g} / \mathrm{ml}$, R\&D Systems), rat antimouse CD14 ( $25 \mu \mathrm{g} / \mathrm{ml}$, R\&D Systems), mouse anti-IgG isotype control (25 $\mu \mathrm{g} / \mathrm{ml})$, mouse anti-human TLR2 $(25 \mu \mathrm{g} / \mathrm{ml}$, Invivogen), human IgA2 isotype control ( $25 \mu \mathrm{g} / \mathrm{ml}$, Invivogen), human anti-human TLR4 (25 $\mu \mathrm{g} / \mathrm{ml}$, Invivogen), and POS prepared as previously described (Sennlaub et al., 2013).

Reverse transcription and real-time PCR and ELISA. IL-6, CCL2, and IL- $1 \beta$ RT-PCRs using Sybr Green (Invitrogen) and ELISAs using mouse or human IL-6 DuoSet (R\&D Systems), mouse or human CCL2 Duoset (R\&D Systems), and human APOE Pro kit (Mabtech) were performed as previously described (Sennlaub et al., 2013; Hu et al., 2015; Levy et al., 2015).

Statistical analysis. GraphPad Prism 5 (GraphPad Software) was used for data analysis and graphic representation. All values are reported as mean \pm SEM. Statistical analysis was performed by one-way or two-way ANOVA followed by Dunnett's post test or Mann-Whitney test for comparison among means depending on the experimental design. The $p$ values are indicated in the figure legends. 

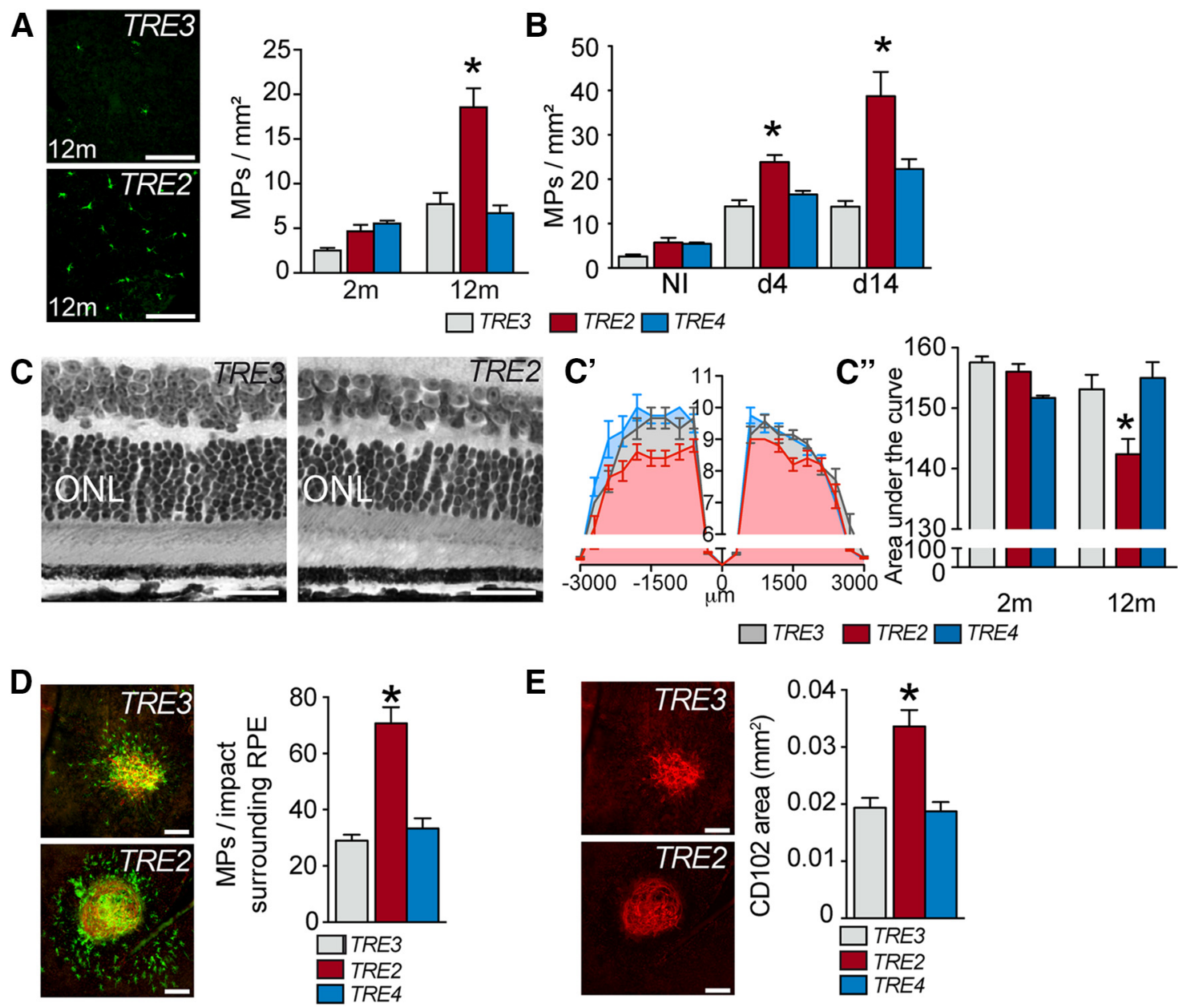

Figure 1. The APOE2 allele leads to age- and stress-related subretinal MP accumulation, retinal degeneration, and exacerbated choroidal neovascularization. $A$, Representative 12 -month-old IBA-1-stained RPE flatmounts of TRE3 and TRE2 mice and quantification of subretinal IBA- ${ }^{+}{ }^{+}$MPs in 2-and 12-month-old mice of the indicated strains $(n=9-20 /$ group $) .{ }^{*} p<0.0001,12$ months versus TRE3 control (ANOVA/Dunnett's multiple-comparison test). B, Quantification of subretinal IBA-1 ${ }^{+}$MPs after a $4 \mathrm{~d}$ light challenge followed by $10 \mathrm{~d}$ of normal light conditions (d14) of 2-month-old mice of the indicated strains ( $n=14-16 /$ group). ${ }^{*} p<0.0001$, versus TRE3 control at $14 \mathrm{~d}$ (ANOVA/Dunnett's multiple-comparison test). C, Micrographs taken $1000 \mu \mathrm{m}$ from the optic nerve of 12-month-old TRE3 and TRE2 mice. 0NL, Outer nuclear layer. $C^{\prime}$, Photoreceptor nuclei rows at increasing distances ( $-3000 \mu \mathrm{m}$ : inferior pole; $3000 \mu \mathrm{m}$ : superior pole) from the optic nerve $(0 \mu \mathrm{m})$ in 12-month-old mice. $C^{\prime \prime}$, Quantification of the area under the curve of photoreceptor nuclei row counts of 2-and 12-month-old transgenic mouse strains $(n=4-7)$. ${ }^{*} p=0.0102$, versus TRE3 control at 12 months (ANOVA/Dunnett's multiple-comparison test). Mice were taken from several ( $\geq 3$ ) independent cages for the quantifications. D, CD102 (red) and IBA-1 (green) immunohistochemistry and quantification of subretinal IBA- $1^{+} \mathrm{MPs}$ on the RPE counted at a distance of $0-500 \mu \mathrm{m}$ to $\mathrm{CD} 102^{+}$CNV $7 \mathrm{~d}$ after the laser injury of 2-month-old mice of the indicated strains $\left(n=8-10 /\right.$ group). ${ }^{*} p<0.0001$ (one-way ANOVA/Dunnett's multiple-comparison test). $E$, CD102 immunohistochemistry and quantification of CD102 area on RPE/choroidal flatmount from 2-month-old transgenic strains, $7 \mathrm{~d}$ after laser injury ( $n=8-10 /$ group). ${ }^{*} p<0.0001$ (one-way ANOVA/Dunnett's multiple-comparison test). TRE2-4, Targeted replacement mice expressing human APOE isoforms Scale bars: $A, C-E, 50 \mu \mathrm{m}$.

\section{Results}

The APOE2 allele leads to age- and stress-related subretinal MP accumulation, retinal degeneration, and exacerbated choroidal neovascularization

The subretinal space, located between the RPE and the POS, does not contain significant numbers of MPs under normal conditions (Penfold et al., 2001; Gupta et al., 2003; Combadière et al., 2007; Levy et al., 2015). This is likely the result of physiologically low levels of chemoattractants along with strong immunosuppressive RPE signals that quickly eliminate infiltrating MPs (Sennlaub et al., 2013; Levy et al., 2015). We have previously shown that the lack of the tonic inhibitory CX3CL1/CX3CR1 signal, observed in CX3cr1-deficient mice, is sufficient to induce pathogenic chronic subretinal MP accumulation as a consequence of increased recruitment and decreased elimination (Combadière et al., 2007; Sennlaub et al., 2013; Levy et al., 2015). We showed that this accumulation is dependent on the overexpression of APOE in Cx3cr1-deficient
MPs (Levy et al., 2015). To evaluate a potential role of the human APOE isoforms in subretinal inflammation, we used targeted replacement mice expressing human isoforms (TRE2, TRE3, and TRE4) (Sullivan et al., 1997). We first backcrossed the strains with C57BL/6J mice to eliminate the $C r b 1^{r d 8}$ contamination in the three strains, which can lead to AMD-like features (Mattapallil et al., 2012). The mice were raised under $12 \mathrm{~h}$ light/ $12 \mathrm{~h}$ dark cycles at 100-500 lux at the cage level, with no additional cover in the cage, the conditions that induce MP accumulation in Cx3cr1-deficient mice with age (Combadière et al., 2007). Quantification of subretinal IBA- $1^{+} \mathrm{MPs}$ on retinal and RPE/choroidal flatmounts of 2- and 12-month-old TRE2, TRE3, and TRE4 mice revealed that TRE2 mice develop age-dependent subretinal MP accumulation compared with TRE3 and TRE4 mice (Fig. 1A). Similarly, TRE2 mice accumulated significantly more subretinal MPs after a $4 \mathrm{~d}$ light challenge, and the MPs continued to accumulate after return for 10 additional days in normal light conditions (Fig. 1B; the intensity of our light challenge model 

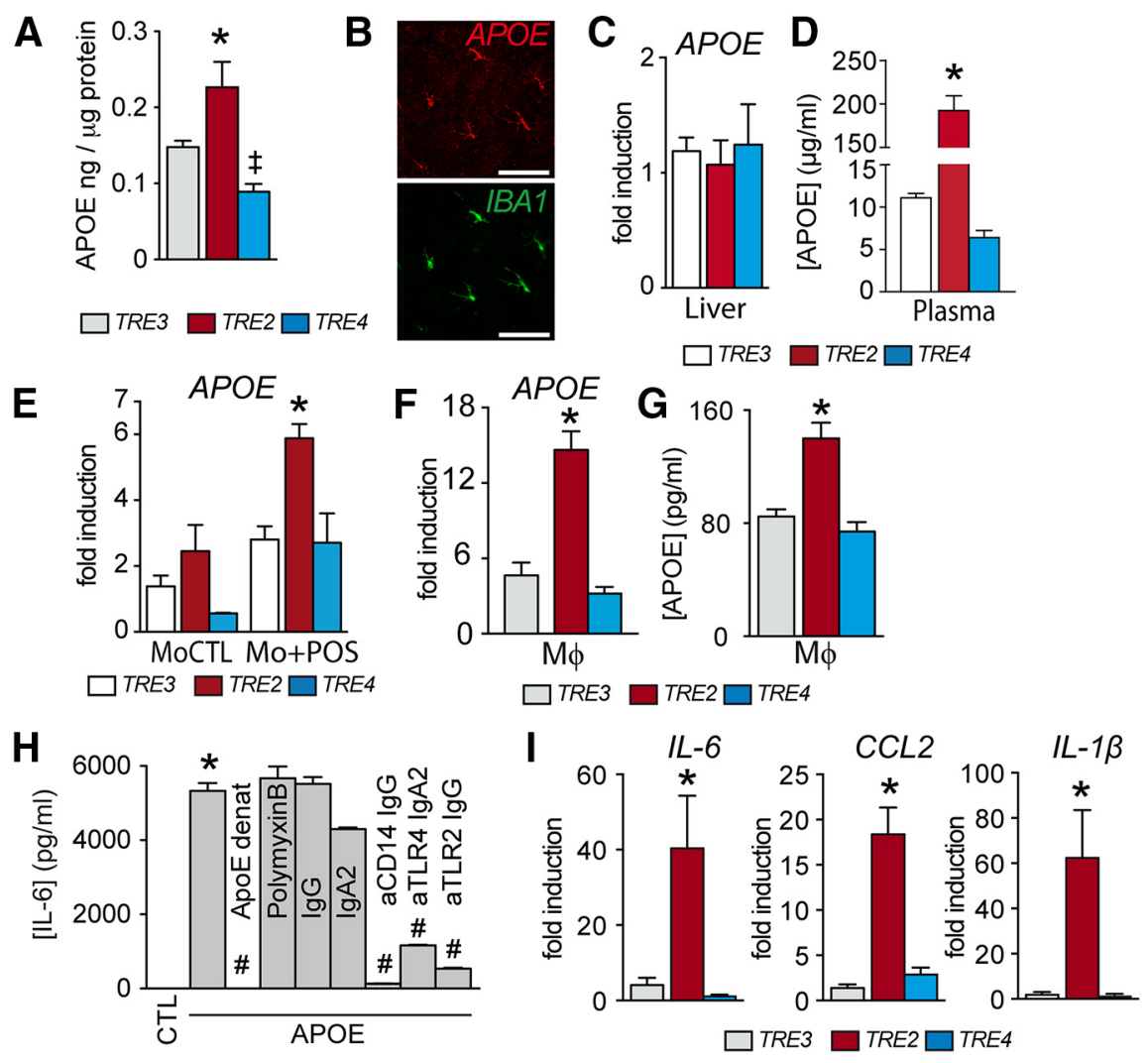

Figure 2. The APOE2 allele increases APOE levels in the eye and APOE transcription and IIRC activation in MPs. A, APOE ELISA of homogenates of PBS-perfused posterior segments of 12-month-old TRE2, TRE3, and TRE4 mice ( $n=5$ or $6 /$ group). ${ }^{*} p=0.0027$, versus TRE3 control (one-way ANOVA/Dunnett's multiple-comparison test). $\neq p=0.0027$ (one-way ANOVA/Dunnett's multiplecomparison test). $\boldsymbol{B}$, Immunohistochemistry of APOE (red, top) and IBA-1 (green, bottom) of the subretinal side of a retinal flatmount from a 12-month-old TRE2 mouse (representative of three independent experiments; experiments omitting the primary antibody immunostaining served as negative controls). C, Quantitative RT-PCR of ApoE mRNA normalized with S26 mRNA of liver extracts from transgenic replacement mice expressing human APOE isoforms (TRE2, TRE3, and TRE4 mice, $n=3$ ). D, ELISA quantification of APOE plasma concentrations in transgenic replacement mice expressing human APOE isoforms (TRE2, TRE3, and TRE4 mice, $n=3$ ). ${ }^{*} p<0.0001$, versus TRE3 control (ANOVA/ Dunnett's multiple-comparison test). E, Quantitative RT-PCR of ApoEmRNA normalized with S26 mRNA of bone marrow-derived monocytes from transgenic replacement mice expressing human APOE isoforms (TRE2, TRE3, and TRE4 mice) cultured for $3 \mathrm{~d}$ with or without porcine photoreceptor outer segments to simulate subretinal monocyte to macrophage differentiation ( $n=6 /$ group). ${ }^{*} p=0.0033$, Mo + POS versus TRE3 control (ANOVA/ Dunnett's multiple-comparison test). $\boldsymbol{F}$, Quantitative RT-PCR of ApoE mRNA normalized with $S 26$ mRNA of peritoneal M $\phi$ s from TRE mice cultured for $24 \mathrm{~h}(n=6) .{ }^{*} p<0.0001$, versus TRE3 control (ANOVA/Dunnett's multiple-comparison test). G, APOE-ELISA of supernatants of peritoneal M $\phi$ s from TRE mice cultured for $24 \mathrm{~h}(n=6) .{ }^{*} p<0.0001$, versus TRE3 control (ANOVA/Dunnett's multiple-comparison test). $\boldsymbol{H}$, Human IL-6 ELISA of supernatants from human monocytes incubated for $24 \mathrm{~h}$ in control medium, APOE3 $(5 \mu \mathrm{g} / \mathrm{ml})$, heat-denaturated APOE3 (dAPOE3, $5 \mu \mathrm{g} / \mathrm{ml})$, APOE3 $(5 \mu \mathrm{g} / \mathrm{ml})$, and polymyxin B $(25 \mu \mathrm{g} / \mathrm{ml})$, APOE3 $(5$ $\mu \mathrm{g} / \mathrm{ml}$ ), and rat lgG1 isotype, or human IgA2 isotype control, or mouse lgG1 isotype control, or rat anti-CD14 lgG1 antibody, or human anti-TLR4 IgGA2 antibody, or mouse anti-TLR2 lgG1 antibody (all antibodies at $25 \mu \mathrm{g} / \mathrm{ml}$ ) $\left(n=4-6 /\right.$ group). ${ }^{*} p<$ 0.0001, APOE3 versus CTL (one-way ANOVA/Bonferroni multiple-comparison test). $" p<0.0001$, dAPOE3 versus APOE3 (one-way ANOVA/Bonferroni multiple-comparison test). $" p<0.0001$, APOE3 lgG versus APOE3 aCD14 Ab (one-way ANOVA/Bonferron multiple-comparison test). ${ }^{\#} p<0.0001$, APOE3 IgG versus APOE3 aTLR4 Ab (one-way ANOVA/Bonferroni multiple-comparison test). ${ }^{~} p<0.0001$, APOE3 IgA versus APOE3 aTLR2 Ab (one-way ANOVA/Bonferroni multiple-comparison test). I, Quantitative RT-PCR of II-6, $C \mathrm{Cl}-2$, and III $\beta$ mRNA normalized with S26 mRNA $(n=6)$ of peritoneal M $\varphi$ s from TRE mice cultured for $24 \mathrm{~h} .{ }^{*} p=$ 0.0069 , versus TRE3 control IL-6 (ANOVA/Dunnett's multiple-comparison test). ${ }^{*} p<0.0001$, versus TRE3 control CCL2 (ANOVA/ Dunnett's multiple-comparison test). ${ }^{*} p=0.0097$, versus TRE3 control IL-1 $\beta$ (ANOVA/Dunnett's multiple-comparison test). TRE2 -4 , Targeted replacement mice expressing human APOE isoforms. Scale bar: $\boldsymbol{B}, 50 \mu \mathrm{m}$.

used herein was calibrated to induce subretinal inflammation in inflammation-prone $C x 3 \mathrm{cr} 1^{\text {GFP/GFP }}$ mice but not in WT mice) (Sennlaub et al., 2013).

We also observed a thinning of the outer nuclear layer that contains the photoreceptor nuclei on histological retinal sections from 12-month-old TRE2 mice compared with TRE3 mice (Fig. $1 C$; micrographs taken at equal distance from the optic nerve). Photoreceptor nuclei row counts (Fig. $1 C^{\prime}$ ) and calculation of the area under the curve (Fig. $1 C^{\prime \prime}$ ) revealed that the age-related accumulation of subretinal MPs in TRE2 mice is associated with significant photoreceptor cell loss compared with TRE3 and TRE4 mice.

In addition, in laser-induced $\mathrm{CNV}$, subretinal IBA- ${ }^{+}$MPs (green staining, counted on the RPE at a distance of $0-500$ $\mu \mathrm{m}$ to $\mathrm{CD} 102{ }^{+} \mathrm{CNVs}$, red staining) were significantly more numerous in TRE2 mice $7 \mathrm{~d}$ after a laser impact (Fig. 1D) and had developed significantly greater $\mathrm{CNV}$ lesions (Fig. 1E) compared with the other strains.

Together, our data demonstrate that TRE2 mice, expressing the APOE2 AMD risk allele, develop age-related subretinal inflammation and photoreceptor degeneration and exaggerated inflammation and $\mathrm{CNV}$ after laser injury similar to late AMD.

The APOE2 allele increases $A P O E$ levels in the eye and $A P O E$ transcription and innate immunity receptor cluster (IIRC) activation in MPs

We previously showed that the levels of soluble APOE are elevated in adult TRE2 mouse brains and diminished in TRE4 brains compared with TRE3 mice in a model of AD (Bales et al., 2009). Similarly, ELISA of APOE levels of homogenates of PBS-perfused posterior segments (retina and RPE/choroid plexus) of 12-month-old mice revealed significantly higher levels of APOE in TRE2 mice compared with TRE3 and TRE4 mice (Fig. 2A). Furthermore, immunohistochemical localization of APOE on retinal flatmounts of TRE2 mice (Fig. 2B, red staining) revealed strong APOE expression in subretinal IBA- $1^{+}$MPs (Fig. 2B, green staining).

The polymorphism rs7412 that defines the APOE2 isoform also leads to the loss of a CPG site in the APOE2 allele that has been shown to moderately, but significantly, increase $A P O E$ transcription in brain astrocytes, but not in hepatocytes (Yu et al., 2013). Our data confirm that APOE transcription in hepatocytes does not differ between genotypes (Yu et al., 2013) (Fig. 2C, RTPCR) and that APOE concentrations in the blood were significantly increased in TRE2 mice (Fig. 2D, blood plasma ELISA), shown to be due to its decreased clearance rate (Mahley and Rall, 2000). However, bone marrow-derived monocytes (cultured with POS for $3 \mathrm{~d}$ to mimic subretinal macrophage differentiation) (Fig. 2E, RTPCR) and peritoneal macrophages (Fig. 2F, RT-PCR) from TRE2 mice transcribed significantly higher levels of $A p o E$ mRNA compared with MPs of the other mouse strains. Ac- 
cordingly, the APOE secretion of TRE2 mice macrophages was robustly increased (Fig. 2G, ELISA of supernatant) compared with the other groups.

APOE and APOA-I have been shown to activate the TLR2-TLR4 CD14dependent IIRC in mouse peritoneal macrophages in the absence of pathogenderived ligands and to induce inflammatory cytokines, such as IL-6 (Smoak et al., 2010; Levy et al., 2015), but also CCL2 (shown for APOA-I) (Smoak et al., 2010). We here show that human blood-derived $\mathrm{CD} 14^{+}$monocytes significantly secrete IL-6 after $24 \mathrm{~h}$ of recombinant lipid-free APOE3 stimulation (Fig. $2 \mathrm{H}$ ) similar to mouse macrophages. Ninety minute heat denaturation completely abolished the induction, whereas the LPS inhibitor polymyxin B did not, confirming that LPS contamination of APOE3 is not accountable for the effect, as shown for APOA-I using multiple approaches (Smoak et al., 2010). This induction was due to the activation of the TLR2-TLR4 CD14-dependent IIRC, as neutralizing antibodies to CD14, TLR2, and TLR4 inhibited this effect, compared with control antibodies (Fig. $2 H$ ). Accordingly, peritoneal macrophages from TRE2 mice that express increased amounts of APOE (Fig. 2C,D) also transcribed significantly more IL-6, CCL2, and IL- $1 \beta$ compared with macrophages of the other isoforms (Fig. 2I).

Together, our results show that the APOE2 allele increases APOE levels in the tissue and APOE expression in MPs. We confirm that APOE activates the IIRC and show that the excessive APOE expression in macrophages from TRE2 mice is associated with increased production of inflammatory cytokines in vitro.

\section{IIRC inhibition reduces subretinal MP accumulation and choroidal neovascularization in TRE2 mice in vivo}

To evaluate whether increased IIRC activation is implicated in subretinal MP accumulation observed in TRE2 mice in vivo, we inhibited the IIRC by an intravitreal injection of a CD14neutralizing antibody in the laser-induced CNV model (Figure 3). The antibody, which blocks APOE-dependent cytokine induction (Levy et al., 2015), inhibited subretinal MP accumulation around the laser injury, quantified on IBA1-stained RPE/ choroidal flatmounts (Fig. $3 A$ ) and $\mathrm{CD} 102^{+} \mathrm{CNV}$ formation (Fig. 3B) at day 7 after laser injury of TRE2 mice compared with control IgG.

These results confirm that the CD14-dependent inflammatory cytokine induction participates in subretinal MP accumulation in TRE2 mice in vivo, similar to $C \times 3 c r 1^{\mathrm{GFP} / \mathrm{GFP}}$ mice (Levy et al., 2015).

\section{The APOE4 allele protects APOE-overexpressing} Cx3cr1 ${ }^{\text {GFP/GFP }}$ mice from subretinal MP accumulation, retinal degeneration, and exacerbated choroidal neovascularization Cx3crl-deficient mice lack the tonic inhibitory signal of neuronal CX3CL1 and develop subretinal MP accumulation and concomitant photoreceptor degeneration with age when raised in cyclic light at 100-500 lux (Combadière et al., 2007; Chinnery et al., 2012; Sennlaub et al., 2013; Hu et al., 2015; Levy et al., 2015). The accumulation can be prevented by raising the animals in darkness (Combadière et al., 2007) or in dim light conditions (Luhmann et
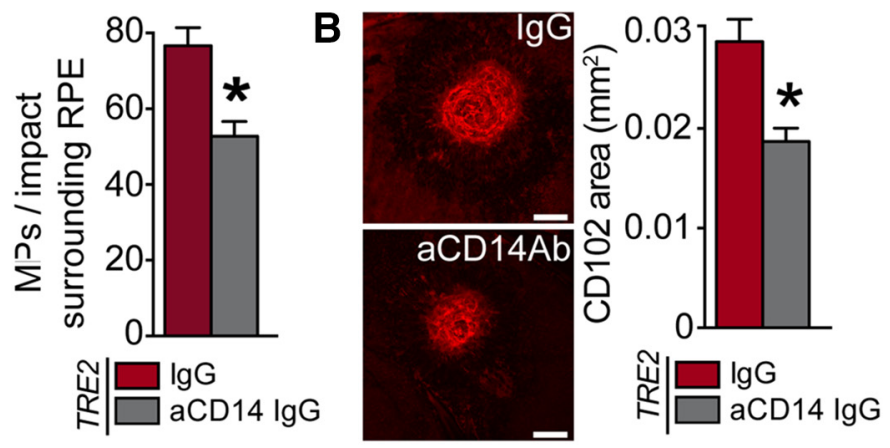

al., 2013) and be accelerated by a light challenge (Sennlaub et al., 2013; Hu et al., 2015; Levy et al., 2015) (for more details, see Sennlaub et al., 2013, mini review in supplemental data). Although these features do not mimic all the aspects of AMD (Drusen formation and RPE atrophy), they do model subretinal inflammation and associated photoreceptor degeneration, two hallmarks of AMD (Gupta et al., 2003). Cx3cr1 deletion also increases subretinal MP accumulation in diabetes (Kezic et al., 2013), in a paraquat-induced retinopathy model (Chen et al., 2013), and in a retinitis pigmentosa model (Peng et al., 2014). We previously demonstrated that pathogenic MPs accumulate in Cx3cr1-deficient mice due to the overexpression of APOE, IL-6, and CCL2 (Sennlaub et al., 2013; Levy et al., 2015). To evaluate a possible influence of the APOE4 isoform in a model of pathological subretinal inflammation, we crossed TRE3 and TRE4 mice to Cx3cr1 ${ }^{\text {GFP/GPP }}$ mice (Levy et al., 2015).

Quantification of subretinal IBA-1 ${ }^{+}$MPs on retinal and $\mathrm{RPE} /$ choroidal flatmounts of 2- and 12-month-old $C \times 3 c r 1^{G F P / G F P}$ TRE3 mice and $C \times 3 c r 1^{G F P / G F P}$ TRE4 mice revealed that the age-dependent subretinal MP accumulation observed in $C \times 3 c r 1^{G F P / G F P}$ TRE3 mice was prevented in $C \times 3 c r 1^{\text {GFP/GFP }}$ TRE4 mice (Fig. 4A). A $4 \mathrm{~d}$ light challenge led to similar initial subretinal MP accumulation, but the increase of MPs after return to normal light conditions was significantly blunted in C $x 3 \mathrm{cr} 1^{\text {GFP/GFP }}$ TRE4 mice compared with $\mathrm{C} \times 3 \mathrm{cr} 1^{\text {GFP/GFP }}$ TRE3 mice (Fig. 4B).

Furthermore, micrographs of histological sections of 12-monthold mice revealed a thicker outer nuclear layer in $C \times 3 \mathrm{cr} 1^{\text {GFP/GFP }}$ TRE4 mice compared with the thinned $C \times 3 \mathrm{cr} 1^{\text {GFP/GFP }}{ }^{\text {TRE3 }}$ mice (Fig. 4C). Photoreceptor nuclei row counts (Fig. $4 C^{\prime}$ ) and calculation of the area under the curve (Fig. $4 C^{\prime \prime}$ ) show that the inhibition of the agerelated accumulation of subretinal MPs in $C \times 3 \mathrm{cr} 1^{\text {GFP/GFP }}$ TRE4 mice compared with $C \times 3 \mathrm{cr} 1^{G F P / G F P}$ TRE3 mice significantly inhibited the associated photoreceptor cell loss. The age-related subretinal MP accumulation and photoreceptor degeneration observed in $C \times 3 \mathrm{cr} 1^{\text {GFP/GFP }}$ TRE3 mice are significantly increased compared with TRE3 mice presented in Figure 1, similar to $C \times 3 \mathrm{cr} 1^{\mathrm{GFP} / \mathrm{GFP}}$ mice expressing mouse APOE (Sennlaub et al., 2013) $\left(\mathrm{MP} / \mathrm{mm}^{2}\right.$ of 12-month-old mice: TRE3 mice: $7.315 \pm 1.72$ SEM; CX3cr1 ${ }^{\text {GFP/GFP } T R E 3 ~ m i c e: ~} 16.6 \pm 2.22$ SEM; area under the curve: TRE3 mice: $148.3 \pm 1.52$ SEM; $C \times 3 c r 1^{\text {GFP/GFP }}{ }^{\text {TRE3 mice: } 137.3 \pm}$ 2.12 SEM). 

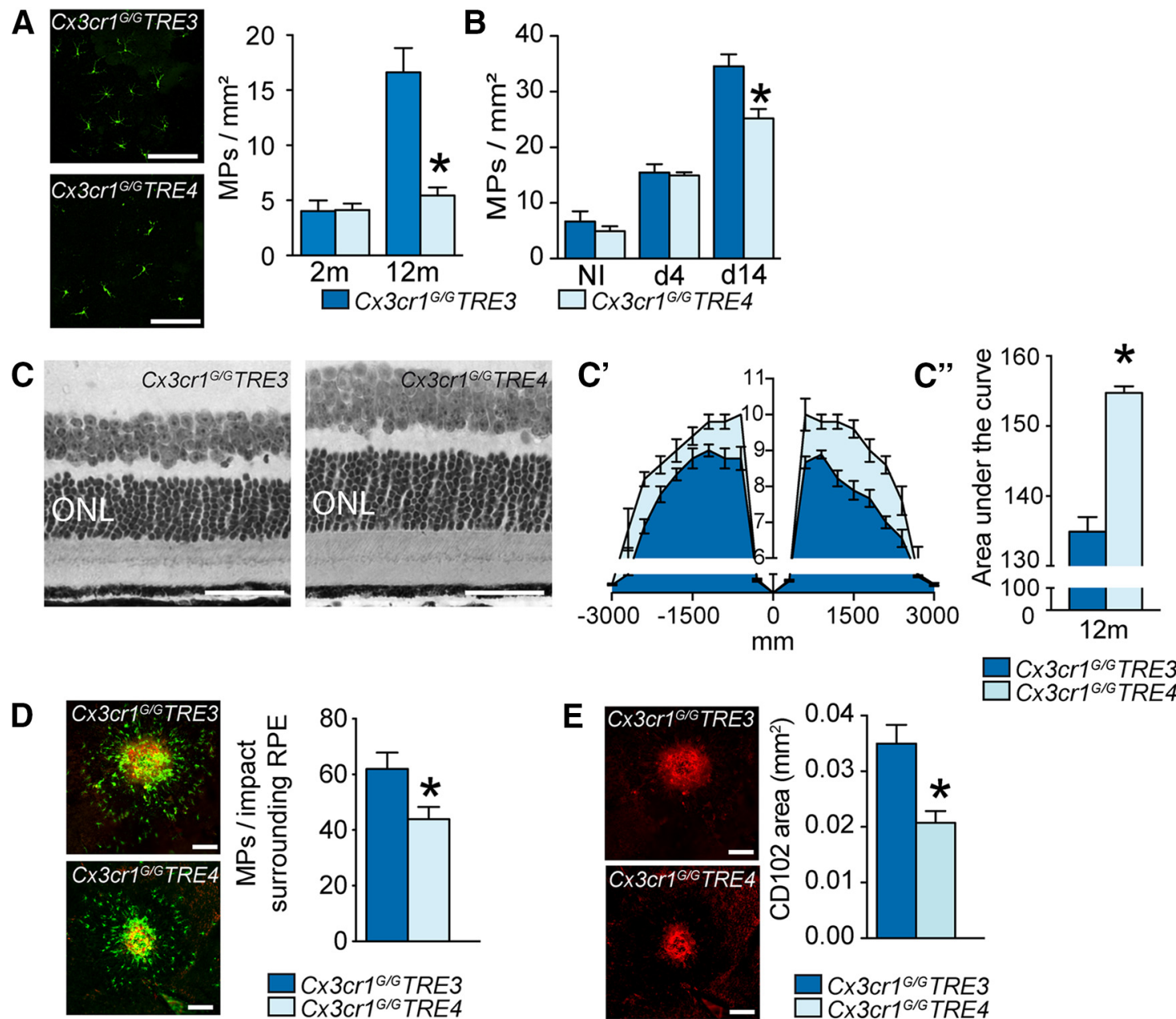

$\square \mathrm{C} \times 3 \mathrm{cr} 1^{\mathrm{G} / \mathrm{G}} \mathrm{TRE3}$
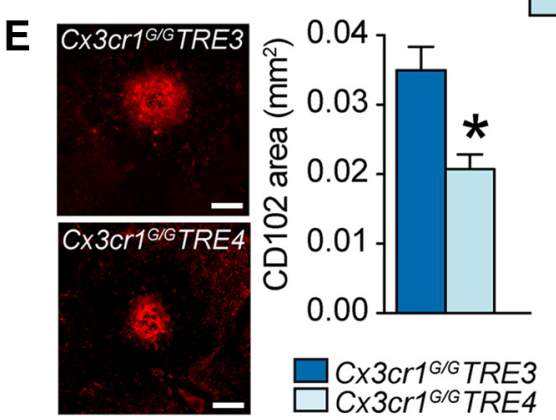

Figure 4. The $A P O E 4$ allele protects APOE-overexpressing $C \times 3 c r 1{ }^{\text {GPP/GFP }}$ mice from subretinal MP accumulation, retinal degeneration, and exacerbated choroidal neovascularization. $A$, Repre-

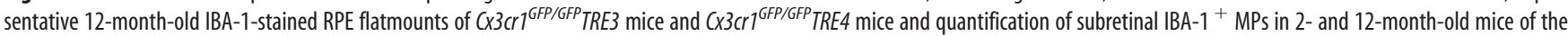
indicated strains ( $n=8-13$ /group). ${ }^{*} p=0.0034$ (Mann-Whitney $t$ test at 12 months). $B$, Quantification of subretinal IBA- $1^{+}$MPs after a $4 \mathrm{~d}$ light challenge followed by $10 \mathrm{~d}$ of normal light conditions (d14) of 2-month-old mice of the indicated strains ( $n=18$ /group). ${ }^{*} p=0.0036$ (Mann-Whitney $t$ test at d14). C, Micrographs, taken $1000 \mu \mathrm{m}$ from the optic nerve of 12 -month-old

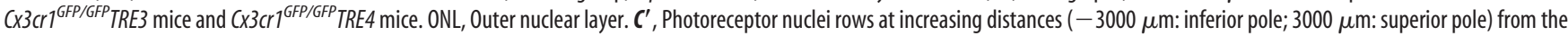
optic nerve $(0 \mu \mathrm{m})$ in 12-month-old mice. $C^{\prime \prime}$, Quantification of the area under the curve of photoreceptor nuclei row counts of 12-month-old transgenic mouse strains $(n=5-9)$. ${ }^{*} p=0.0032$ (Mann-Whitney $t$ test). Mice were taken from several $(\geq 3$ ) independent cages for the quantifications. D, CD102 (red) and IBA-1 (green) immunohistochemistry and quantification of subretinal IBA- $1^{+}$MPs on the RPE counted at a distance of $0-500 \mu \mathrm{m}$ to CD102 ${ }^{+}$CNV $14 \mathrm{~d}$ after the laser injury of 2-month-old mice of the indicated strains $(n=7 / \mathrm{group}) .{ }^{*} p=0.0182$ (Mann-Whitney $t$ test). $E$, CD102 immunohistochemistry and quantification of CD102 area on RPE/choroidal flatmount from 2-month-old transgenic strains, $14 \mathrm{~d}$ after laser injury ( $n=7 /$ group). ${ }^{*} p=0.0034$ (Mann-Whitney $t$ test). Scale bars: $A, C-E, 50 \mu \mathrm{m}$.

Moreover, laser-induced subretinal IBA- $1^{+}$MPs in 2-monthold mice (green staining) adjacent to $\mathrm{CD} 102{ }^{+} \mathrm{CNVs}$ (red staining) was again significantly inhibited in $C \times 3 \mathrm{cr} 1^{\text {GFP/GFP }}$ TRE4 mice compared with CX3 $\mathrm{crl}^{\text {GFP/GFP }}$ TRE3 mice (Fig. $4 D$ ) and had developed significantly greater $\mathrm{CNV}$ lesions at $14 \mathrm{~d}$ after laser injury (Fig. 4E) compared with the other strains.

In summary, our data demonstrate that the APOE4 allele, which is protective for AMD, inhibits subretinal inflammation and concomitant degeneration and $\mathrm{CNV}$ in $\mathrm{Cx} 3 \mathrm{crl} 1$ deficiency compared with APOE3.

The APOE4 allele decreases ocular APOE levels in $C \times 3 \mathrm{cr} 1^{G F P / G F P}$ mice and activates the IIRC inefficiently To investigate whether the APOE3 and APOE4 allele influences the APOE level in the eyes of $C \times 3 c r 1^{G F P / G F P} T R E$ mice, we analyzed APOE levels of homogenates of PBS-perfused posterior segments (retina and RPE/choroid plexus) of 12-month-old mice. APOE levels were significantly lower in homogenates of 12-month-old CX3cr1 ${ }^{\text {GFP/GFP }}$ TRE4 mice compared with

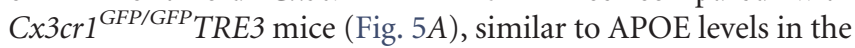
eyes of TRE mice (see above) and brains of PDAPP mice expressing human APOE isoforms (Bales et al., 2009).

APOA-I and APOE likely activate the IIRC by modifying the cholesterol content of the lipid rafts in which they are located (Smoak et al., 2010). As the APOE4 isoform has an impaired capacity to promote cholesterol efflux and transport (Heeren et al., 2004; Mahley et al., 2009), we next tested its ability to activate the IIRC of blood-derived human monocytes in culture. Interestingly, stimulation of monocytes for $24 \mathrm{~h}$ by recombinant APOE4 induced significantly less IL-6 and CCL2 secretion compared with the induction of the cytokines by equimolar concentrations of APOE3 (Fig. 5B).

APOE transcription (Fig. 5C, RT-PCR) and APOE secretion (Fig. 5D, ELISA of supernatant) in peritoneal macrophages from CX3 $\mathrm{Cr}^{\text {GFP/GFP }}{ }^{\text {TRE } 3}$ mice and $C \times 3 \mathrm{cr} 1^{\text {GFP/GFP }}$ TRE4 mice were comparable, similar to previous reports from astrocytes: the 
APOE4 allele did not diminish APOE production (Yu et al., 2013). However, in accordance with a decreased ability to activate the IIRC, peritoneal macrophages from $C \times 3 \mathrm{cr}^{\text {GFP/GFP }}$ TRE4 mice transcribed significantly less CCL2 compared with macrophages from $C \times 3 c r 1^{G F P / G F P}$ TRE3 mice, whereas the IL-6 transcription was variable, but not significantly different (Fig. 5E).

Together, our results show that the APOE4 allele leads to decreased APOE tissue levels and to a reduced capacity to activate the IIRC and induce CCL2 in MPs.

\section{Discussion}

We have previously shown that the lack of the tonic inhibitory CX3CL1/CX3CR1 signal, observed in Cx3cr1-deficient mice, is sufficient to induce pathogenic chronic subretinal MP accumulation due to increased CCL2-dependent monocyte recruitment and IL-6-dependent decrease of subretinal MP elimination (Combadière et al., 2007; Sennlaub et al., 2013; Hu et al., 2015; Levy et al., 2015). We showed that this accumulation is dependent on the overexpression of APOE in Cx3cr1-deficient MPs (Levy et al., 2015). As the APOE isoforms are associated with significant differences in APOE levels in humans (Mahley and Rall, 2000) and in humanized transgenic mice expressing APOE isoforms (Bales et al., 2009; Yu et al., 2013), we here evaluated the consequences of the three isoforms on chorioretinal homeostasis.

Our study shows that TRE2 mice, carrying the AMD risk allele, develop age-, light-, and laser-induced subretinal MP accumulation associated with photoreceptor degeneration and excessive CNV. TRE2 mice displayed increased tissue levels of APOE measured in whole retinal/choroidal protein extracts compared with TRE3 and TRE4 mice. This increase is likely due to reduced LDLR-dependent APOE2 uptake (Fryer et al., 2005) of APOE that is produced in the RPE, the inner retina and by subretinal MPs (Anderson et al., 2001; Levy et al., 2015). Similar to $C X 3 C R 1^{G F P / G F P}$ mice and AMD patients (Levy et al., 2015), subretinal MPs in TRE2 mice stained strongly positive for APOE. In vitro, we show that the APOE2 allele is associated with increased APOE transcription and secretion in macrophages from TRE2 mice, as previously shown for astrocytes (Yu et al., 2013). The APOE levels in and around subretinal MPs are therefore likely elevated because of increased APOE transcription and decreased LDLR-dependent clearance in the tissue. It is not yet clear to what extent APOE from nonmyeloid cells participates in the subretinal inflammation and whether extracellular or intracellular APOE within the MPs is the determining factor.

APOE is capable of activating the CD14/TLR2/TLR4dependent IIRC and inducing IL-6, as previously shown for mouse macrophages (Smoak et al., 2010; Levy et al., 2015). We here confirm that APOE can induce inflammatory cytokines in a similar manner in human monocytes. Moreover, macrophages from TRE2 mice that express significantly higher levels of APOE

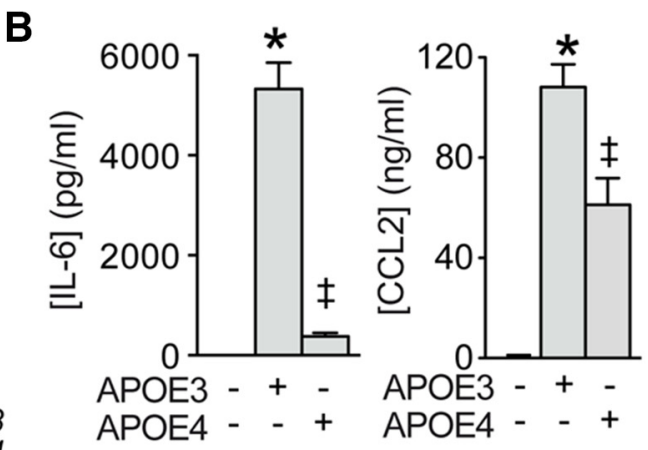

E $\quad I L-6$
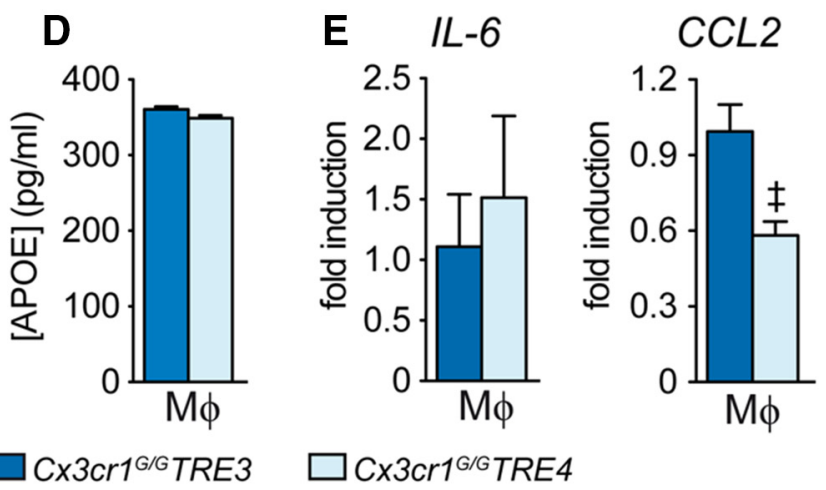

\section{$\square C \times 3 c r 1^{1 / G} T R E 3 \quad \square C \times 3 c r 1^{G / G}$ TRE4}

P/GFP mice and activates the IIRC inefficiently. $A, A P O E$ ELISA mogenates of PBS-perfused posterior segments of 12-month-old $C \times 3 \mathrm{cr} 1^{\text {GFP/GFP }}$ TRE3 mice and $\left.C \times 3 \mathrm{cr}\right)^{\text {GFP/GFP }}$ TRE4 mice $(n=$ TRE mice cultured for $24 \mathrm{~h}$. $\boldsymbol{E}$, Quantitative RT-PCR of II-6 and C 2 mRNA normalized with S26 mRNA $(n=5-10)$ of peritoneal M $\phi s$ from TRE mice cultured for $24 \mathrm{~h}$. $\neq p=0.0035$, compared with CCL2 from (x3 cr1G/GTRE3 M $\phi$ s (Mann-Whitney $t$ test).

also transcribed higher levels of inflammatory cytokines, such as IL-6, CCL2, and IL-1 $\beta$, in accordance with an APOE activation of the IIRC and similar to APOE-overexpressing Cx3crl-deficient macrophages (Sennlaub et al., 2013; Hu et al., 2015; Levy et al., 2015). We previously showed that CCL2 (Sennlaub et al., 2013) and IL-6 (Levy et al., 2015) promote subretinal MP accumulation by increasing monocyte recruitment and decreasing MP clearance, respectively. Indeed, inhibition of the IIRC by a CD14blocking antibody in laser-injured TRE2 mice decreased subretinal MP accumulation and neovascularization. These results demonstrate that IIRC activation is significantly involved in the subretinal MP accumulation in TRE2 mice in vivo. Together, $C \times 3 c r 1^{G F P / G F P}$ mice and TRE2 mice both overexpress APOE in mononuclear phagocytes, although for different reasons. In both mouse strains, the increased APOE is associated with IIRC activation, CCL2 and IL-6 induction, and pathogenic subretinal inflammation. Although these features do not mimic all the aspects of AMD (Drusen formation and RPE atrophy), they do model subretinal inflammation and associated photoreceptor degeneration, two hallmarks of AMD (Gupta et al., 2003). We previously demonstrated the importance of APOE in this process, as APOE deletion protected $C \times 3 \mathrm{cr} 1^{G F P / G F P}$ mice against the inflammation (Levy et al., 2015). Interestingly, increased levels of CCL2 and IL-6 are also observed in late AMD (Seddon et al., 2005; Jonas et al., 2010; Sennlaub et al., 2013; Chalam et al., 2014), where chronic MP accumulation is observed (Penfold et al., 2001; Gupta et al., 2003; Combadière et al., 2007; Sennlaub et al., 2013; 
Levy et al., 2015). The observation that inhibition of subretinal MP accumulation in a variety of animal models represses CNV (Sakurai et al., 2003; Tsutsumi et al., 2003; Liu et al., 2013) and degeneration (Guo et al., 2012; Rutar et al., 2012; Suzuki et al., 2012; Kohno et al., 2013) strongly suggests that chronic subretinal inflammation partakes in AMD pathogenesis.

The chronic nonresolving inflammation in AMD is associated with an increase in APOE (Klaver et al., 1998; Anderson et al., 2001; Levy et al., 2015) similar to other inflammatory conditions (Rosenfeld et al., 1993). To evaluate whether a potential influence of the protective APOE4 allele would become apparent in a situation of increased inflammation and APOE abundance, we crossed TRE3 and TRE4 mice to the APOE-overexpressing $C \times 3 \mathrm{cr} 1^{\text {GFP/GFP }}$ mice. In the inflammatory context of $C \times 3 \mathrm{crl}^{\text {GFP/GFP }}$ mice, the APOE4 allele led to diminished APOE levels and the APOE4 allele protected $C \times 3 \mathrm{cr} 1^{\text {GFP/GFP }}$ mice against harmful subretinal MP accumulation observed in APOE3carrying $C \times 3 \mathrm{cr} 1^{G F P / G F P}$ mice. APOE4 is characterized, among others, by its decreased capacity to transport cholesterol compared with APOE3 (Heeren et al., 2004) and might thereby be less capable of modifying the cholesterol content of the lipid rafts and activating the IIRC (Smoak et al., 2010). Indeed, our results show that recombinant APOE4 induced less IL-6 and CCL2 compared with equimolar APOE3 concentrations in human monocytes in vitro. Similarly, macrophages from $C \times 3 c r 1^{G F P / G F P}$ TRE4 mice transcribed less CCL2 compared with macrophages from $C \times 3 c r 1^{G F P / G F P}$ TRE3 mice, although their APOE expression was comparable. It is not clear why $C x 3 c r 1^{G F P / G F P}$ TRE4 macrophages did not differ from $C \times 3 \mathrm{cr} 1^{\text {GFP/GFP }}$ TRE3 macrophages in terms of IL-6 transcription levels. Other unknown regulatory elements likely influence the transcription of the individual cytokines in macrophages, and the interplay of $C \times 3 c r 1$ deficiency and the human APOE3 and APOE4 isoform in the mouse macrophages might affect these pathways. We previously showed that CCL2 inhibition in $C \times 3 \mathrm{cr}^{G F P / G F P}$ mice significantly inhibited age-, laser-, and light-induced subretinal MP accumulation (Sennlaub et al., 2013) and diminished production of CCL2, as a result of reduced APOE concentrations and APOE4's impaired capacity to induce cytokines might explain the reduced inflammation and inhibition of degeneration and CNV observed in $\mathrm{C} \times 3 \mathrm{cr} 1^{\text {GFP/GFP }}$ TRE4 mice.

To our knowledge, this is the first study to describe a comprehensive pathomechanism of the involvement of APOE isoforms in AMD that is in accordance with the clinical observation of the APOE2 allele being an AMD risk factor and the APOE4 allele an AMD-protective genetic factor. One previous study demonstrated that TRE4 mice on high-fat diet develop lipid accumulations in the Bruch's membrane, proposed as similar to early AMD (Malek et al., 2005), which are also observed in $A p o E^{-/-}$mice (Ong et al., 2001). Although these observations might apply to early AMD, they are unlikely to play a role in late AMD in which increased APOE immunoreactivity is observed (Klaver et al., 1998; Anderson et al., 2001; Levy et al., 2015) and in which the APOE4 allele plays a protective role (McKay et al., 2011). The involvement of increased reverse cholesterol transport in AMD might also be supported by the observation that APOA-I levels are elevated in the vitreous of AMD patients (Koss et al., 2014). Furthermore, a polymorphism of the ATP-binding cassette transporter 1 (associated with low high-density lipoprotein and therefore possibly impaired reverse cholesterol transport) has recently been shown to be protective against advanced AMD (Chen et al., 2010).
Our study also sheds an interesting light on the puzzling differences of the APOE isoform association with AMD (McKay et al., 2011) and AD (Mahley and Rall, 2000), two major age-related neurodegenerative diseases. In $\mathrm{AD}$, the APOE4 allele is associated with greater $\beta$-amyloid burden, possibly due to decreased APOE tissue concentrations and reduced efficacy in clearance of $\beta$-amyloid clearance via multiple pathways (Bales et al., 2009; Mahley et al., 2009). Cx3cr1 $1^{G F P / G F P}$ mice that express increased amounts of APOE in all MPs, including MCs (Levy et al., 2015), are protected against $\beta$-amyloid deposition in $\mathrm{AD}$ mouse models (Lee et al., 2010). In AMD, we show that excessive APOE expression associated with the AMD-risk APOE2 allele leads to the induction of inflammatory cytokines that promote pathogenic subretinal inflammation (Figs. 1, 2, 3) (Levy et al., 2015), similar to $C x 3 c r 1$-deficient mice (Combadière et al., 2007; Sennlaub et al., 2013; Peng et al., 2014; Levy et al., 2015). On the other hand, we show that the APOE4 allele is protective in the context of APOE overexpression of Cx3cr1 ${ }^{\text {GFP/GFP }}$ mice (Levy et al., 2015), due to decreased APOE tissue concentrations (Riddell et al., 2008; Bales et al., 2009; Sullivan et al., 2011) and its reduced capacity to induce inflammatory cytokines (Figs. 4, 5).

Together, our study shows that the APOE2 allele leads to increased APOE expression, IIRC activation, and subretinal inflammation, whereas the APOE4 allele diminishes IIRC activation and inflammation. Our study provides the rationale for the previously unexplained implication of the APOE genotype in AMD and opens avenues toward therapies inhibiting pathogenic chronic inflammation in late AMD.

\section{References}

Anderson DH, Ozaki S, Nealon M, Neitz J, Mullins RF, Hageman GS, Johnson LV (2001) Local cellular sources of apolipoprotein E in the human retina and retinal pigmented epithelium: implications for the process of drusen formation. Am J Ophthalmol 131:767-781. CrossRef Medline

Bales KR, Liu F, Wu S, Lin S, Koger D, DeLong C, Hansen JC, Sullivan PM, Paul SM (2009) Human APOE isoform-dependent effects on brain beta-amyloid levels in PDAPP transgenic mice. J Neurosci 29:6771-6779. CrossRef Medline

Chalam KV, Grover S, Sambhav K, Balaiya S, Murthy RK (2014) Aqueous interleukin-6 levels are superior to vascular endothelial growth factor in predicting therapeutic response to bevacizumab in age-related macular degeneration. J Ophthalmol 2014:502174. CrossRef Medline

Chen M, Luo C, Penalva R, Xu H (2013) Paraquat-induced retinal degeneration is exaggerated in CX3CR1-deficient mice and is associated with increased retinal inflammation. Invest Ophthalmol Vis Sci 54:682-690. CrossRef Medline

Chen W, Stambolian D, Edwards AO, Branham KE, Othman M, Jakobsdottir J, Tosakulwong N, Pericak-Vance MA, Campochiaro PA, Klein ML, Tan PL, Conley YP, Kanda A, Kopplin L, Li Y, Augustaitis KJ, Karoukis AJ, Scott WK, Agarwal A, Kovach JL, et al. (2010) Genetic variants near TIMP3 and high-density lipoprotein-associated loci influence susceptibility to age-related macular degeneration. Proc Natl Acad Sci U S A 107: 7401-7406. CrossRef Medline

Chinnery HR, McLenachan S, Humphries T, Kezic JM, Chen X, Ruitenberg MJ, McMenamin PG (2011) Accumulation of murine subretinal macrophages: effects of age, pigmentation and CX(3)CR1. Neurobiol Aging 33:1769-1776. CrossRef Medline

Combadière C, Feumi C, Raoul W, Keller N, Rodéro M, Pézard A, Lavalette S, Houssier M, Jonet L, Picard E, Debré P, Sirinyan M, Deterre P, Ferroukhi T, Cohen SY, Chauvaud D, Jeanny JC, Chemtob S, Behar-Cohen F, Sennlaub F (2007) CX3CR1-dependent subretinal microglia cell accumulation is associated with cardinal features of age-related macular degeneration. J Clin Invest 117:2920-2928. CrossRef Medline

Dong LM, Weisgraber KH (1996) Human apolipoprotein E4 domain interaction: arginine 61 and glutamic acid 255 interact to direct the preference for very low density lipoproteins. J Biol Chem 271:19053-19057. CrossRef Medline

Fryer JD, Demattos RB, McCormick LM, O’Dell MA, Spinner ML, Bales KR, 
Paul SM, Sullivan PM, Parsadanian M, Bu G, Holtzman DM (2005) The low density lipoprotein receptor regulates the level of central nervous system human and murine apolipoprotein $\mathrm{E}$ but does not modify amyloid plaque pathology in PDAPP mice. J Biol Chem 280:25754-25759. CrossRef Medline

Guo C, Otani A, Oishi A, Kojima H, Makiyama Y, Nakagawa S, Yoshimura N (2012) Knockout of ccr2 alleviates photoreceptor cell death in a model of retinitis pigmentosa. Exp Eye Res 104:39-47. CrossRef Medline

Gupta N, Brown KE, Milam AH (2003) Activated microglia in human retinitis pigmentosa, late-onset retinal degeneration, and age-related macular degeneration. Exp Eye Res 76:463-471. CrossRef Medline

Heeren J, Grewal T, Laatsch A, Becker N, Rinninger F, Rye KA, Beisiegel U (2004) Impaired recycling of apolipoprotein E4 is associated with intracellular cholesterol accumulation. J Biol Chem 279:55483-55492. CrossRef Medline

Hu SJ, Calippe B, Lavalette S, Roubeix C, Montassar F, Housset M, Levy O, Delarasse C, Paques M, Sahel JA, Sennlaub F, Guillonneau X (2015) Upregulation of P2RX7 in Cx3cr1-deficient mononuclear phagocytes leads to increased interleukin-1beta secretion and photoreceptor neurodegeneration. J Neurosci 35:6987-6996. CrossRef Medline

Jonas JB, Tao Y, Neumaier M, Findeisen P (2010) Monocyte chemoattractant protein 1, intercellular adhesion molecule 1 , and vascular cell adhesion molecule 1 in exudative age-related macular degeneration. Arch Ophthalmol 128:1281-1286. CrossRef Medline

Kezic JM, Chen X, Rakoczy EP, McMenamin PG (2013) The effects of age and $\mathrm{Cx} 3 \mathrm{cr} 1$ deficiency on retinal microglia in the Ins2Akita diabetic mouse. Invest Ophthalmol Vis Sci 54:854-863. CrossRef Medline

Klaver CC, Kliffen M, van Duijn CM, Hofman A, Cruts M, Grobbee DE, van Broeckhoven C, de Jong PT (1998) Genetic association of apolipoprotein E with age-related macular degeneration. Am J Hum Genet 63:200206. CrossRef Medline

Kohno H, Chen Y, Kevany BM, Pearlman E, Miyagi M, Maeda T, Palczewski K, Maeda A (2013) Photoreceptor proteins initiate microglial activation via Toll-like receptor 4 in retinal degeneration mediated by all-transretinal. J Biol Chem 288:15326-15341. CrossRef Medline

Koss MJ, Hoffmann J, Nguyen N, Pfister M, Mischak H, Mullen W, Husi H, Rejdak R, Koch F, Jankowski J, Krueger K, Bertelmann T, Klein J, Schanstra JP, Siwy J (2014) Proteomics of vitreous humor of patients with exudative age-related macular degeneration. PLoS One 9:e96895. CrossRef Medline

Lee S, Varvel NH, Konerth ME, Xu G, Cardona AE, Ransohoff RM, Lamb BT (2010) CX3CR1 deficiency alters microglial activation and reduces betaamyloid deposition in two Alzheimer's disease mouse models. Am J Pathol 177:2549-2562. CrossRef Medline

Levy O, Calippe B, Lavalette S, Hu SJ, Raoul W, Dominguez E, Housset M, Paques M, Sahel JA, Bemelmans AP, Combadière C, Guillonneau X, Sennlaub F (2015) Apolipoprotein E promotes subretinal mononuclear phagocyte survival and chronic inflammation in age-related macular degeneration. EMBO Mol Med 7:211-226. CrossRef Medline

Liu J, Copland DA, Horie S, Wu WK, Chen M, Xu Y, Paul Morgan B, Mack M, Xu H, Nicholson LB, Dick AD (2013) Myeloid cells expressing VEGF and arginase-1 following uptake of damaged retinal pigment epithelium suggests potential mechanism that drives the onset of choroidal angiogenesis in mice. PLoS One 8:e72935. CrossRef Medline

Luhmann UF, Carvalho LS, Robbie SJ, Cowing JA, Duran Y, Munro PM, Bainbridge JW, Ali RR (2013) Ccl2, Cx3crl and Ccl2/Cx3cr1 chemokine deficiencies are not sufficient to cause age-related retinal degeneration. Exp Eye Res 107:80-87. CrossRef Medline

Mahley RW, Rall SC Jr (2000) Apolipoprotein E: far more than a lipid transport protein. Annu Rev Genomics Hum Genet 1:507-537. CrossRef Medline

Mahley RW, Weisgraber KH, Huang Y (2009) Apolipoprotein E: structure determines function, from atherosclerosis to Alzheimer's disease to AIDS. J Lipid Res 50 [Suppl]:S183-S188.

Malek G, Johnson LV, Mace BE, Saloupis P, Schmechel DE, Rickman DW, Toth CA, Sullivan PM, Bowes Rickman C (2005) Apolipoprotein E allele-dependent pathogenesis: a model for age-related retinal degeneration. Proc Natl Acad Sci U S A 102:11900-11905. CrossRef Medline

Mattapallil MJ, Wawrousek EF, Chan CC, Zhao H, Roychoudhury J, Ferguson TA, Caspi RR (2012) The rd8 mutation of the Crb1 gene is present in vendor lines of C57BL/6N mice and embryonic stem cells, and confounds ocular induced mutant phenotypes. Invest Ophthalmol Vis Sci 53:29212927. CrossRef Medline
McKay GJ, Patterson CC, Chakravarthy U, Dasari S, Klaver CC, Vingerling JR, Ho L, de Jong PT, Fletcher AE, Young IS, Seland JH, Rahu M, Soubrane G, Tomazzoli L, Topouzis F, Vioque J, Hingorani AD, Sofat R, Dean M, Sawitzke J, et al. (2011) Evidence of association of APOE with agerelated macular degeneration: a pooled analysis of 15 studies. Hum Mutat 32:1407-1416. CrossRef Medline

Ong JM, Zorapapel NC, Rich KA, Wagstaff RE, Lambert RW, Rosenberg SE, Moghaddas F, Pirouzmanesh A, Aoki AM, Kenney MC (2001) Effects of cholesterol and apolipoprotein $\mathrm{E}$ on retinal abnormalities in ApoEdeficient mice. Invest Ophthalmol Vis Sci 42:1891-1900. Medline

Penfold PL, Madigan MC, Gillies MC, Provis JM (2001) Immunological and aetiological aspects of macular degeneration. Prog Retin Eye Res 20:385-414. CrossRef Medline

Peng B, Xiao J, Wang K, So KF, Tipoe GL, Lin B (2014) Suppression of microglial activation is neuroprotective in a mouse model of human retinitis pigmentosa. J Neurosci 34:8139-8150. CrossRef Medline

Peri F, Nüsslein-Volhard C (2008) Live imaging of neuronal degradation by microglia reveals a role for v0-ATPase a1 in phagosomal fusion in vivo. Cell 133:916-927. CrossRef Medline

Riddell DR, Zhou H, Atchison K, Warwick HK, Atkinson PJ, Jefferson J, Xu L, Aschmies S, Kirksey Y, Hu Y, Wagner E, Parratt A, Xu J, Li Z, Zaleska MM, Jacobsen JS, Pangalos MN, Reinhart PH (2008) Impact of apolipoprotein E (ApoE) polymorphism on brain ApoE levels. J Neurosci 28:1144511453. CrossRef Medline

Rosenfeld ME, Butler S, Ord VA, Lipton BA, Dyer CA, Curtiss LK, Palinski W, Witztum JL (1993) Abundant expression of apoprotein E by macrophages in human and rabbit atherosclerotic lesions. Arterioscler Thromb 13:1382-1389. CrossRef Medline

Rutar M, Natoli R, Provis JM (2012) Small interfering RNA-mediated suppression of Ccl2 in Muller cells attenuates microglial recruitment and photoreceptor death following retinal degeneration. J Neuroinflammation 9:221. CrossRef Medline

Sakurai E, Anand A, Ambati BK, van Rooijen N, Ambati J (2003) Macrophage depletion inhibits experimental choroidal neovascularization. Invest Ophthalmol Vis Sci 44:3578-3585. CrossRef Medline

Seddon JM, George S, Rosner B, Rifai N (2005) Progression of age-related macular degeneration: prospective assessment of C-reactive protein, interleukin 6, and other cardiovascular biomarkers. Arch Ophthalmol 123: 774-782. CrossRef Medline

Sennlaub F, Auvynet C, Calippe B, Lavalette S, Poupel L, Hu SJ, Dominguez E, Camelo S, Levy O, Guyon E, Saederup N, Charo IF, Rooijen NV, Nandrot E, Bourges JL, Behar-Cohen F, Sahel JA, Guillonneau X, Raoul W, Combadière C (2013) CCR2 (+) monocytes infiltrate atrophic lesions in agerelated macular disease and mediate photoreceptor degeneration in experimental subretinal inflammation in $\mathrm{Cx} 3 \mathrm{crl}$ deficient mice. EMBO Mol Med 5:1775-1793. CrossRef Medline

Smoak KA, Aloor JJ, Madenspacher J, Merrick BA, Collins JB, Zhu X, Cavigiolio G, Oda MN, Parks JS, Fessler MB (2010) Myeloid differentiation primary response protein 88 couples reverse cholesterol transport to inflammation. Cell Metab 11:493-502. CrossRef Medline

Sullivan PM, Mezdour H, Aratani Y, Knouff C, Najib J, Reddick RL, Quarfordt SH, Maeda N (1997) Targeted replacement of the mouse apolipoprotein E gene with the common human APOE3 allele enhances diet-induced hypercholesterolemia and atherosclerosis. J Biol Chem 272: 17972-17980. CrossRef Medline

Sullivan PM, Han B, Liu F, Mace BE, Ervin JF, Wu S, Koger D, Paul S, Bales KR (2011) Reduced levels of human apoE4 protein in an animal model of cognitive impairment. Neurobiol Aging 32:791-801. CrossRef Medline

Suzuki M, Tsujikawa M, Itabe H, Du ZJ, Xie P, Matsumura N, Fu X, Zhang R, Sonoda KH, Egashira K, Hazen SL, Kamei M (2012) Chronic photo-oxidative stress and subsequent MCP-1 activation as causative factors for age-related macular degeneration. J Cell Sci 125:2407-2415. CrossRef Medline

Tsutsumi C, Sonoda KH, Egashira K, Qiao H, Hisatomi T, Nakao S, Ishibashi M, Charo IF, Sakamoto T, Murata T, Ishibashi T (2003) The critical role of ocular-infiltrating macrophages in the development of choroidal neovascularization. J Leukoc Biol 74:25-32. CrossRef Medline

Yu CE, Cudaback E, Foraker J, Thomson Z, Leong L, Lutz F, Gill JA, Saxton A, Kraemer B, Navas P, Keene CD, Montine T, Bekris LM (2013) Epigenetic signature and enhancer activity of the human APOE gene. Hum Mol Genet 22:5036-5047. CrossRef Medline 